Удк 338.48

DOI https://doi.org/10.32851/2708-0366/2021.7.9

Лисюк Т.В.

кандидат педагогічних наук, доцент кафредри туризму та готельного господарства,

Державний вищий навчальний заклад «Волинський національний університет імені Лесі Українки» ORCID: https://orcid.org/0000-0003-1629-9652

Терешук О.C.

кандидат географічних наук, доцент кафедри туризму та готельного господарства,

Державний вищий навчальний заклад «Волинський національний університет імені Лесі Українки» ORCID: https://orcid.org/0000-0001-8131-1270

Демчук O.A. студентка,

Державний вищий навчальний заклад «Волинський національний університет імені Лесі Українки»

Lysiuk Tetiana, Tereshchuk Oksana, Demchuk Olga State Higher Educational Institution "Lesya Ukrainka Volyn National University»

\title{
ЕКСКУРСІЙНА ДІЯЛЬНІСТЬ У ВОЛИНСЬКІЙ ОБЛАСТІ В УМОВАХ ПАНДЕМІЇ
}

\section{EXCURSION ACTIVITIES IN VOLYN REGION IN A PANDEMIC CONDITION}

\begin{abstract}
У статті наведено шляхи розв'язання основних проблем на ринку індустрії туризму. Розглянуто кризові явища в екскурсійній діяльності, спричинені COVID-19, у Волинській області. Зважаючи на третинний сектор економіки, туризм становить основну частину сочіально-економічного розвитку. Але у зв'язку з поширенням коронавірусу туристична індустрія є одним із тих секторів економіки, щзо постраждав найбільше, зокрема через обмеження на пересування туристів, карантин, заборону авіаперевезень тощя. 3'ясовано, щзо сьогодні спостерігається значне відставання у темпах відновлення туристичного сектору, щцо ставить під серйозну загрозу економіку Волинської області. Разом із тим КП «Центр туристичної інформації та послуг» надав пропозиції щзодо виходу з кризи, утілення яких сприятиме розвитку екскурсійної діяльності, а також урегулюванню наслідків пандемії, які впливають на економіку туристичної галузі Волинської області.
\end{abstract}

Ключові слова: екскурсійна діяльність, туризм, пандемія, криза, економіка.

В статье приведены пути решения главных проблем на рынке индустрии туризма. Рассмотрены кризисные явления в экскурсионной деятельности, вызванные COVID-19, в Вольнской области. Принимая во внимание третичный сектор экономики, туризм составляет основную часть сочиально-экономического развития. Но в связи с распространением коронавируса туристическая индустрия является одним из тех секторов экономики, который пострадал больше всего, в частности через ограничение на передвижение туристов, карантин, запрет авиаперевозок и тому подобное. Выяснено, что сегодня наблюдается значительное отставание в темпах возобновления туристического сектора, который ставит под серьезную угрозу экономику Волынской области. Вместе с тем КП «Центр туристической информации и услуг» представил предложения относительно выхода из кризиса, воплощение которых будет содействовать развитию экскурсионной деятельности, а также урегулированию последствий пандемии, которые влияют на экономику туристической отрасли Вольнской области.

Ключевые слова: экскурсионная деятельность, туризм, пандемия, кризис, экономика. 
The article outlines ways to solve the main problems in the tourism industry market. Crisis phenomena in excursion activities by COVID-19 in Volyn region are considered. Given the tertiary sectors of the economy, tourism is a major part of socio-economic development. However, due to the spread of the coronavirus, the tourism industry is one of the sectors of the economy that has suffered the most, in particular due to restrictions on the movement of tourists, quarantine, air travel bans and more. It was found that today there is a significant lag in the pace of recovery of the tourism sector, which poses a serious threat to the economy of Volyn region. At the same time, the Center for Tourist Information and Services provided proposals for overcoming the crisis, the implementation of which will promote the development of sightseeing activities, as well as address the effects of the pandemic that affect the economy of the tourism industry of Volyn region. At present, it is difficult to predict the ways development of excursion activity in a pandemic, because strategic plans in the current environment are difficult to plan, but still expected to increase the number of domestic tourism consumers, who due to quarantine restrictions, began to develop and promote inbound and domestic tourism. As for consequences of the COVID-19 in excursion activity, the Volyn region is in a relatively better situation than the Lviv region. A city like Truskavets has suffered the most from quarantine restrictions, where for 20 thousand people living in the city, there are 600 doctors and 2 thousand medical staff who suddenly lost their jobs. Guides predict that excursion activities in the Volyn region will resume in two years. It is expected that in 2022 it will be possible to return to the influx of tourists that was in 2019. But this will happen under favorable conditions, when vaccination against COVID-19 will be carried out, when excursion activities will attract foreign tourists. The time of the so-called tourist silence should be used to creation cultural initiatives to encourage tourists to visit the Volyn region. It should be noted that the Volyn region is gradually implementing measures that reduce the impact of COVID-19 on the excursion activities, namely, introduces tours online and create new types of tourism products that could be of interest to tourists. And thanks to a number of these measures, the region can continue to develop its tourism potential.

Key words: excursion activity, tourism, pandemic, crisis, economy.

Постановка проблеми. Через пандемію коронавірусу екскурсійна діяльність туристичних підприємств Волинської області переорієнтувалася на користь інноваційних шляхів розвитку.

Пандемія коронавірусу позбавила можливості екскурсійну діяльність вільно функціонувати, що автоматично створило надзвичайно серйозні виклики туристичній галузі. Волинська область опинилася перед перспективою зриву екскурсійного сезону, тому COVID-19, окрім загрози здоров'ю, створив проблеми для багатьох екскурсантів. Музеї були змушені миритися зі зменшенням кількості відвідувачів та доходів від екскурсій.

У Волинській області моментально відреагували на необхідність мінімізувати наслідки пандемії COVID-19, адже численні туроператори, турагенти та екскурсійні бюро зіштовхнулися з економічною проблемою, яку буде складно вирішити, адже сотні людей, що працюють у сфері туризму, залишаться без роботи.

Сьогодні відновлення туристичних підприємств відбувається локально, що значно ускладнює процес упровадження можливих заходів на підтримку туристичної галузі. Після відновлення роботи кількість відвідувачів у вихідні дні зменшилася до показників, які раніше були в будні дні.

Проте починаючи з весни цього року деякі туристично-екскурсійні підприємства Волинської області на базі онлайн-платформ пропонують віртуальні тури до історичних та культурних пам'яток (музеїв, готелів, площ, парків, священних і стародавніх місць тощо).

У період карантинних обмежень, вимушеного простою працівники КП «Центр туристичної інформації та послуг» міста Луцька створили онлайн-крамницю сувенірної продукції у Facebook, яка тепер функціонує на постійній основі.

Розроблено та запроваджено у перелік послуг КП «ЦТІ» екскурсійні тури: «Луцький Street Art», «Луцьк від А до Я», «Луцьк у дарунок», «Прогулянка на катері «На одній хвилі»», «Моє місто - частина України» з майстер-класом «Виготовлення різьбленої свічки» у свічковій майстерні Луцького замку, а також квест «Княжими 
стежками».

Туристично-екскурсійна індустрія вимушена пристосовуватися до істотних змін вимог споживачів, а також адаптуватися до швидко змінюваних епідеміологічних обставин. Щоб не допустити повного колапсу, екскурсійна діяльність у Волинській області має гнучко трансформуватися, забезпечуючи своє функціонування і подолання кризових явищ.

Аналіз останніх досліджень і публікацій. Розвиток туристичної індустрії в умовах пандемії досліджується багатьма вченими. Зокрема, дослідження питань особливостей розвитку туризму викладено у роботах таких закордонних та вітчизняних авторів, як: А. Александрова, Т. Алексєєва, І. Звездовська, Я. Кацемір, В. Костинець, I. Логунцова, К. Мартинович, Л. Оболенцева, М. Романенко, А. Тараненко [1-3; 5; 6; $8-10 ; 12 ; 17]$ Проте подальшого дослідження потребують питання розроблення антикризових заходів функціонування туристичної індустрії в умовах карантинних обмежень та повернення іï до звичних умов функціонування після зняття цих обмежень.

Аналізуючи інформацію, яка висвітлена в літературних джерелах та в мережі Інтернет, серед експертів слід виокремити Олександра Ольшевського, який розповів про туристичну галузь Волині, котра зазнала значних збитків через карантин, а також про надходження до бюджету коштів за 2020 р. [15].

Варто зазначити, що за версією авторитетного профільного всеукраїнського видання Zruchno.Travel ще у докарантинний період обласний центр Волині потрапив у топ-десятку українських міст із найкращими перспективами для розвитку туризму в 2020 p. [15].

Катерина Теліпська, керівниця управління туризму та промоції міста, зазначає: «Зумовлено це не тільки наявними ресурсами (історико-культурна спадщина, культурно-мистецький потенціал, талановита громада), а й розумінням влади, що ця галузь має розвиватися. За минулий рік Луцьк відвідало понад 303 тисячі туристів. Із них $18,6 \%$ - іноземці» [11].

Формулювання цілей статті. Метою статті є обгрунтування стану екскурсійної діяльності туристичних підприємств в умовах пандемії; визначення проблем екскурсійної діяльності у Волинській області; дослідження заходів забезпечення протиепідеміологічної стійкості та повноцінного функціонування туристичної сфери в карантинних умовах.

Виклад основного матеріалу. Найперша галузь світової економіки, що постраждала від глобальної пандемії COVID-19, - туристична. Тим не менше навіть у цій ситуації можна знайти вихід: переорієнтуватися з виїзного туризму до внутрішнього та відкрити для себе рідну країну із зовсім іншого боку. У Волинській області присутні всі чинники для розвитку туризму, а саме:

- наявність екскурсійних об'єктів і можливість їх зручного використання;

- можливість отримання пільг і знижок на туристичні послуги;

- освітній та культурний рівень населення.

Екскурсійна діяльність Волинської області пережила чи не найбільш кризовий період за всю історію незалежності. Попит на екскурсійні послуги впав на 90-95\% [2].

У Луцьку екскурсоводи від березня до червня 2020 р. не могли виконувати свої обов'язки. Згодом дозволили проводити екскурсії для невеликих груп. Якщо до пандемії, особливо у вихідні, годі було пройти Старим містом через велику кількість екскурсійних груп, то сьогодні їх зустрінеш зрідка. Сьогодні іноземних туристів у Луцьку практично немає. Згорнувся і діловий туризм, бо всі заплановані конференції перейшли в онлайн-режим.

Основні статистичні показники розвитку туристичної галузі Волинської області за 2020 р. свідчать про спад екскурсійної активності, який відбувся з 2019 по 2020 р. (рис. 1). 


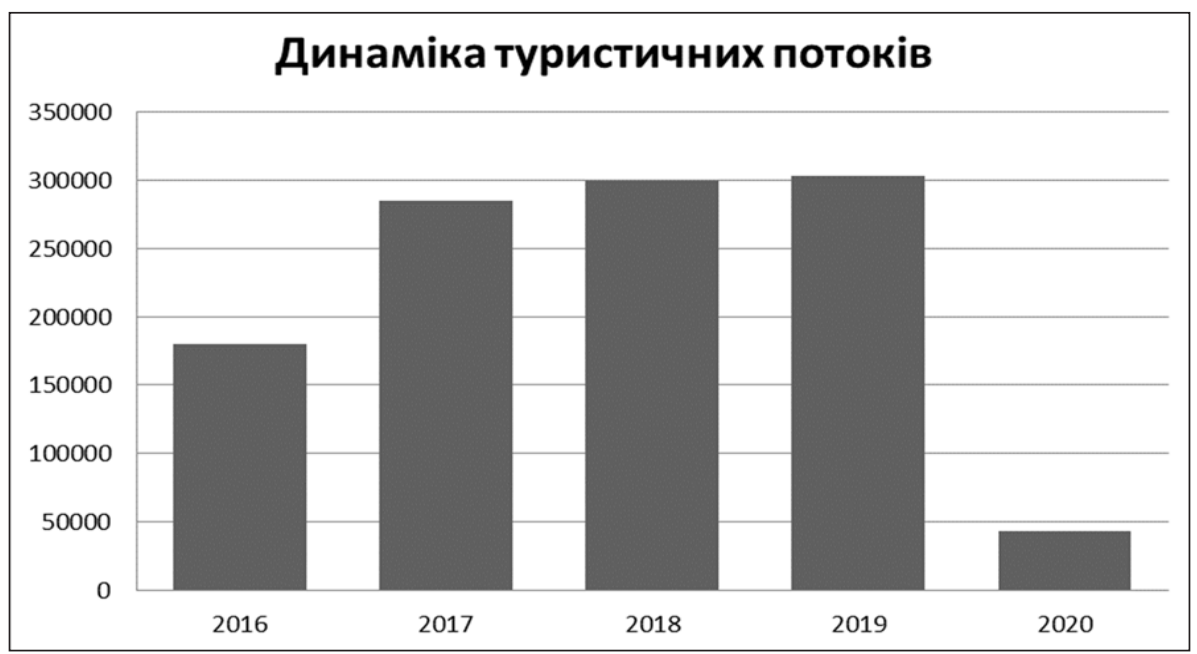

Рис. 1. Динаміка туристичних потоків

Динаміка туристичних потоків за період 2016-2020 pр. указує на те, що починаючи з 2016 р. відбувається їх поступове зростання. Однак структура туристичних потоків у Волинській області останнім часом зазнала змін. Так, якщо 2016 р. переважали іноземні туристичні потоки, то 2020-го їхня частка зменшилися до 90-95\%. Кількість туристів, які виїжджали за кордон, у 2020 р. зменшилася до нуля. Чисельність внутрішніх туристів збільшилася, і причиною цього слугувало закриття кордонів. Така ситуація засвідчує популярність національного туристичного продукту, адже сьогодні світова пандемія вносить зміни в туристичну індустрію та сприяє розвитку внутрішнього туризму [3].

Проте влітку 2021 р. екскурсійна діяльність почала відновлюватися. Свої двері відчинили: Художній музей, Волинський краєзнавчий музей, Музей дзвонів у Луцькому замку, Музей Волинської ікони, Музей книги та інші музеї та екскурсійні об’єкти, які продовжили свою діяльність.

У рамках проєкту «Луцьк+» розроблено 10 туристичних маршрутів, що включають найцікавіші локації міста та інші куточки Волині:

1. Луцьк - Жидичин - Піддубці - Залісочне - Олика.

2. Луцьк - Колодяжне - Нечимне.

3. Луцьк - Рокині -Луцьк - Берестечко - Пляшева.

4. Луцьк - Старий Порицьк - Павлівка - Шацькі озера («Смаколики Волині»).

5. Луцьк - Оконськ - Маневичі - Любешів.

6. Луцьк - Затурці - Устилуг.

7. Луцьк - Цуманська пуща - Лопатень.

8. Луцьк - Зимне - Володимир-Волинський.

9. Луцьк - Дубно.

10. Луцьк - Почаїв - Кременець - Вишнівець.

Екскурсійна сфера зіштовхнулася 3 низкою проблем, спричинених пандемією COVID-19. Причинами нестабільності є досить велика кількість проблем, які сповільнюють розвиток екскурсійного туризму у Волинській області та гальмують розвиток туристичної індустрії, а саме:

- недостатнє фінансування;

- зменшення кількості екскурсій;

- зменшення прибутків; 
- звільнення гідів від роботи;

- зменшення туристичних потоків.

На момент написання публікації у Волинській області було 29 підтверджених випадків захворювання на COVID-19. Згідно зі статистикою Міністерства охорони здоров'я, ми займали 18-е місце за поширенням цієї хвороби в державі. На разі протиепідеміологічні заходи в області полягають в обов'язковому носінні в громадських місцях та транспорті захисної маски, що покриває ніс та рот, дотриманні соціальної дистанції та правил особистої гігієни. Заклади громадського харчування вже працюють для відвідувачів, та приймають гостей на літніх терасах і внутрішніх залах.

У Волинській області з метою недопущення повної стагнації в екскурсійній діяльності, а також банкрутства фахівцями роботодавців у сфері туризму розроблено низку заходів, успішна реалізація яких дасть змогу туристично-екскурсійному бізнесу безпечно функціонувати в умовах карантинних обмежень та активно відновитися після їх закінчення.

За таких умов одними з найважливіших проблем в екскурсійній сфері аналізованої області сьогодні є забезпечення засобів індивідуального захисту, дотримання соціальної дистанції і загалом безпека туристів, яка лягає на плечі екскурсовода, адже відвідувачі повинні:

- обробити руки антисептичним засобом перед входом на територію музею чи іншого екскурсійного об'єкта;

- дотримуватися соціальної дистанції в 1,5 м;

- заходити до закладу та пересуватися по ньому у захисній масці, що прикриває ніс та рот.

За порушення цих обмежень керівництво екскурсійних об'єктів можуть притягати до відповідальності за ст. 44-3 Кодексу України про адміністративні правопорушення. Розмір штрафу для посадових осіб становить від 34,0 до 170,0 тис грн.

На глобальному рівні UNWTO (Всесвітня організація туризму) закликала уряди країн світу максимально сприяти підтримці функціонування туристичної сфери та розробила свої Рекомендації щодо пом'якшення COVID-пандемії на сферу туризму в різних країнах. Документ був розроблений за участю всіх організацій, що входять до складу «Глобального кризового комітету з туризму»:

- WHO (World Health Organization - Всесвітньої організації охорони здоров'я);

- ICAO (International Civil Aviation Organization - Міжнародної організації цивільної авіації);

- IMO (International Maritime Organization - Міжнародної морської організації);

- організаціями приватного сектору: ACI (International Airport Council - Мiжнародної ради аеропортів);

- CLIA (Cruise Lines International Association - Міжнародної асоціації круїзних ліній);

- IATA (International Air Transport Association - Міжнародної асоціації повітряного транспорту);

- WTTC (World Tourism and Travel Council - Всесвітньої ради з туризму та подорожей) [4].

Незважаючи на фактичне послаблення карантинних обмежень, після весняного карантину екскурсійний бізнес усе ще знаходиться під ризиком заборони діяльності в червоних та помаранчевих зонах. Щоправда, повністю забороняти екскурсійну діяльність невиправдано, якщо дотримуватися елементарних санітарних норм та правил.

Пандемія посприяла тому, що Волинська область усе більше відходить від традиційних видів туризму. До запровадження карантинних обмежень туризм у Волинській області на $80 \%$ складався з культурного туризму, гості області, серед яких значну кількість становили іноземці, обов'язково відвідували об'єкти культурної спадщини, 
музеї, фестивалі. Те, що внаслідок запровадження карантину потік туристів майже повністю зупинився, змусило представників культури зосередити свою увагу саме на мешканцях міста та області, збільшити кількість просвітницьких заходів, щоб самі люди усвідомили, де вони живуть, які пам'ятки та об’єкти культури їх оточують [4].

На нашу думку, для того щоб покращити стан екскурсійної діяльності туристичних підприємств в області, потрібно вжити таких заходів:

- поліпшити рівень туристичного обслуговування мешканців та гостей Луцька;

- посилити і стабілізувати співпрацю зі складовими елементами індустрії гостинності міста: музеями, готелями, закладами харчування, навчальними закладами тощо;

- проводити інтелектуально-просвітницькі та пізнавально-розважальні заходи;

- підвищити ефективність використання екскурсійних об'єктів шляхом створення нових екскурсійних маршрутів;

- забезпечити належний рівень промоції міста в Україні та за кордоном;

- поліпшити рівень туристичного інформування про історико-культурну спадщину міста та його культурно-мистецький потенціал;

- збільшити видатки 3 державного бюджету на розвиток туризму та екскурсійної діяльності;

- провести за рахунок держави масові кваліфікаційні навчання персоналу в галузі екскурсійної діяльності із санітарних вимог та протидії епідемії [2].

Нездійснення зазначених заходів може призвести до швидкого звільнення великої кількості працівників без фактичної виплати вихідної допомоги через відсутність обігових коштів, а також імовірних банкрутств тисяч суб'єктів туризму та сотень тисяч супутніх компаній та постачальників туристичної галузі. Саме ці заходи будуть адекватними існуючій ситуації та сприятимуть розвитку туристичної галузі Волинської області.

Висновки. Пандемія COVID-19 спричинила велику кризу екскурсійної галузі. У Волинській області туристичний бізнес шукає вихід зі скрутного становища, будь-які можливості реінтеграції та запропоновані туристам інноваційні туристичні продукти.

Проте, незважаючи на кризові фактори, екскурсійна діяльність повинна знаходити нові варіанти підтримки попиту на свої послуги задля успішного функціонування після зняття карантинних обмежень епідеміологічного характеру. Відкриття нових можливостей забезпечить екскурсантів новим потенціалом інноваційних підходів під час проведення екскурсій у складних умовах функціонування.

Забезпечення стійкості та повноцінного функціонування екскурсійної діяльності у Волинській області в сучасних умовах адаптації до швидко змінюваних епідеміологічних обставин прямо залежить від комплексних, обгрунтованих дій усіх країн світу. Саме цілеспрямовані, узгоджені, послідовні антикризові заходи спроможні реабілітувати сферу послуг. Екскурсійний туризм має активно відкривати нові можливості своєї діяльності задля досягнення стабілізації та підготовки до успішного функціонування у посткарантинний період.

\section{Список використаних джерел:}

1. Александрова А.Ю. Актуальные тенденции развития сферы туризма в глобальных городах мира. Современные проблемы сервиса и туризма. 2015. Т. 9. № 2. С. 5-13.

2. Алексєєва T. Чи має перспективи внутрішній туризм та як йому допомагає держава. URL: https://zaxid.net/chi_maye_perspektivi_vnutrishniy_turizm_ta_\%1 fyak_yomu_\%1fdo\% $1 \mathrm{fpoma}$ gaye_derzhava_n1503523 (дата звернення: 09.06.2021).

3. Звездовська I. Туристичний сезон - 2020: аналіз, прогноз і трохи оптимізму. URL: https:/thepage.ua/ua/exclusive/turistichnij-sezon-2020-analiz-prognoz-i-trohi-optimizmu (дата звернення: 21.11.2020). 
4. Зіганшина А. Дозвілля в умовах карантину: онлайн-сервіси для віртуальних мандрів. URL: https://lpnu.ua/news/2020/dozvillya-v-umovah-karantynuonlayn-servisy-dlya-virtualnyh-mandriv (дата звернення: 09.06.2021).

5. Кацемір Я.В. Соціально-економічні чинники розвитку внутрішнього туризму в Україні. Причорноморські економічні студї. 2020. Вип. 52-2. С. 7-11.

6. Костинець В.В., Костинець Ю.В. Віртуальні подорожі як інструмент просування причорноморського регіону. Причорноморські економічні студіï. 2020. Вип. 52-1. С. 82-85.

7. Кучірка Д. Внутрішній туризм в Україні - на підйомі через COVID-19. Чи надовго? URL: https://www.radiosvoboda.org/a/vnytrishniy-turyzm-v-ukraini-covid19/30726545.html (дата звернення: 09.06.2021).

8. Логунцова И.В. Индустрия туризма в условиях пандемии коронавируса: вызовы и перспективы. Государственное управление. 2020. № 80. С. 49-65.

9. Мартинович К. Правила безопасности: как изменится туризм после карантина. URL: https://story.tutu.ru/pravila-bezopasnosti-kak-izmenitsja-turizm-posle-karantina (дата звернення: 09.06.2021).

10. Оболенцева Л.В., Костіна К.М. Туристичний імідж території: проблеми формування, управління та розвитку. Збірник наукових праць ЧДТУ. 2019. Вип. 52. С. 56-64.

11. Поширення коронавірусу: безвихідь чи поштовх до розвитку? URL: https:/hromadske.volyn.ua/poshyrennia-koronavirusu-bezvykhid-chy-poshtovkh-dlia-rozvytku/ (дата звернення: 09.06.2021).

12. Романенко M. ZOOM чи туристичний бум: чи збільшиться внутрішній туризм після карантину. URL: https://hromadske.ua/posts/zoom-chi-turistichnij-bum-chi-zbilshitsya-vnutrishnijturizm-pislya-karantinu (дата звернення: 09.06.2021).

13. Савицький В. Як врятувати український туризм від наслідків пандемії: досвід країн заходу. URL: https:/ua.news/ua/kak-spasty-ukraynskyj-turyzm-ot-posledstvyjpandemyy-opyt-stranzapada (дата звернення: 09.06.2021).

14. Сущенко Р. Карантин. Як світ рятує туристичну галузь. URL: https://www.ukrinform.ua/ rubric-tourism/3090351-karantin-ak-svit-ratue-turisticnu-galuz.html (дата звернення: 09.06.2021).

15. Туристична галузь Волині зазнала значних збитків через карантин. URL: http:/www.volynpost.com/news/171020-turystychna-galuz-volyni-zaznala-znachnyh-zbytkivcherez-karantyn (дата звернення: 09. 06.2021).

16. Туристичний бізнес під час пандемії: висновки та ключові інсайти. URL: https://eba.com.ua/turystychnyj-biznespid-chas-pandemiyi-vysnovky-ta-klyuchovi-insajty (дата звернення: 09.06.2021)

17. Тараненко А. Карантин вихідного дня та його вплив на сферу туризму. URL: https://biz.nv.ua/ukr/experts/karantin-vihidnogo-dnya-vbivaye-turizm-chi-ye-kompromis-noviniukrajini-50124177.html (дата звернення: 09.06.2021).

\section{References:}

1. Alexandrova A.U. (2015) Current trends in the development of the tourism sector in global cities of the world. Sovremennye problemy servisa i turizma, vol. 9, no. 2, pp. 5-13.

2. Alekseeva T. (2020) Does domestic tourism have prospects and how does the state help it? Available at: https://zaxid.net/chi_maye_perspektivi_vnutrishniy_turizm_ta_\%1fyak_yomu_\%1fdo\%1 fpoma-gaye derzhava n1503523 (accessed 09 June 2021).

3. Zvezdovska I. (2020) Tourist season-2020: analysis, forecast and a little optimism. Available at: https://thepage.ua/ua/exclusive/turistichnij-sezon-2020-analiz-prognoz-i-trohi-optimizmu (accessed 09 June 2021).

4. Ziganshina, A. (2020) Leisure in quarantine: online services for virtual travel. Available at: https://lpnu.ua/news/2020/dozvillya-vumovah-karantynu-onlayn-servisy-dlya-virtualnyh-mandriv (accessed 09 June 2021).

5. Katsemir Ya.V. (2020) Socio-economic factors of domestic tourism development in Ukraine. Black Sea Economic Studies. Issue 52-2, pp. 7-11.

6. Kostynets V.V., Kostynets Yu.V. (2020) Virtual travel as a tool for promoting the Black Sea region. Black Sea Economic Studies. Issue 52-1, pp. 82-85.

7. Kuchirka D. (2020) Domestic tourism in Ukraine - on the rise through Covid-19. Available at: https://www.radiosvoboda.org/a/vnytrishniy-turyzm-v-ukraini-covid19/30726545.html (accessed 09 June 2021). 
8. Loguntsova I.V. (2020) The tourism industry in the context of the coronavirus pandemic: challenges and prospects. Public administration: Electronic bulletin. Issue 80, pp. 49-65.

9. Martinovic,K.(2020) Safety rules: how tourism will change after the quarantine (2020). Available at: https://story.tutu.ru/pravila-bezopasnosti-kak-izmenitsja-turizm-posle-karantina (accessed 09 June 2021).

10. Obolentseva L.V., Kostina K.M. (2019) Tourist image of the territory: problems of formation, management and development. Collection of scientific works of ChSTU. Issue 52, pp. 56-64.

11. Coronavirus spread: dead end or impetus for development? Available at: https:/hromadske.volyn.ua/poshyrennia-koronavirusu-bezvykhid-chy-poshtovkh-dlia-rozvytku/ (accessed 09 June 2021).

12. Romanenko M. (2020) ZOOM or the tourist boom: will domestic tourism increase after quarantine. Available at: https://hromadske.ua/posts/zoom-chi-turistichnij-bum-chi-zbilshitsya-vnutrishnij-turizm-pislya-karantinu (accessed 09 June 2021).

13. Savitsky V. (2020) How to save Ukrainian tourism from the effects of a pandemic: the experience of Western countries. Available at: https:/ua.news/ua/kak-spasty-ukraynskyj-turyzm-ot-posledstvyjpandemyy-opyt-stran-zapada (accessed 09 June 2021).

14. Sushchenko R. (2020) Quarantine. How the world saves the tourism industry. Available at: https://www.ukrinform.ua/rubrictourism/3090351-karantin-ak-svit-ratue-turisticnu-galuz.html (accessed 09 June 2021)

15. The tourism industry in Volyn has suffered significant losses due to quarantine. Available at: http://www.volynpost.com/news/171020-turystychna-galuz-volyni-zaznala-znachnyh-zbytkiv-cherez-karantyn (accessed 09 June 2021).

16. Tourism business during a pandemic: conclusions and key insights (2020). Available at: https://eba.com.ua/turystychnyj-biznespid-chas-pandemiyi-vysnovky-ta-klyuchovi-insajty (accessed 09 June 2021).

17. Taranenko A. (2020) Weekend quarantine and its impact on tourism. Available at: https://biz.nv.ua/ukr/experts/karantin-vihidnogo-dnya-vbivaye-turizm-chi-ye-kompromis-novini-ukrajini-50124177.html (accessed 09 June 2021). 